\title{
TIMING OF ENVIRONMENTAL CHANGE IN CARIBBEAN SHALLOW WATERS RELATIVE TO THE CLOSURE OF THE TROPICAL AMERICAN SEAWAY: EVIDENCE FROM BENTHIC FORAMINIFERA
}

COLLINS, Laurel S., Museum of Paleontology, University of Michigan, Ann Arbor, Michigan, 48109-1079, U.S.A.

The most significant change in Pliocene oceanic circulation resulted from closure of the Tropical American Seaway between the Caribbean Sea and Eastern Pacific Ocean around $3 \mathrm{Ma}$. Faunal changes in Caribbean shallow-water marine organisms such as mollusks and corals have been attributed to possible environmental changes associated with this event, including cyclical cooling, initiation of a carbonate regime in the southern Caribbean, and upwelling of deeper waters on the continental shelf, but their occurrences and timing have been unclear.

This study uses the ecological and evolutionary record of benthic foraminifera of the upper continental slope to inner continental shelf to investigate environmental change in Caribbean shallow waters with respect to final closure of the interoceanic seaway. Benthic foraminifera are useful as environmental indicators so periods of increased taxonomic turnover should correspond to times of environmental change. Over 100 species commonly occurring in deposits of Caribbean Panama and Costa Rica dated from 6.5 to $1.6 \mathrm{~m}$.y. were taxonomically standardized with existing literature and collections to produce stratigraphic ranges within the Caribbean region.

Although an average common species has lived from Early Miocene times until today, an increase in first appearances suggests that an interval of ecological restructuring occurred on the continental shelf to upper slope in latest Miocene time. The last $15 \mathrm{~m} . \mathrm{y}$. includes about $45 \%$ of the first and last appearances, $70 \%$ of which are comparably dated in other Caribbean strata. For the period from 15 to $3 \mathrm{Ma}$, about $75 \%$ of first appearances occurred between 7 and $3 \mathrm{Ma}$, and more than twice as many occurred between 7 and $5 \mathrm{Ma}$ as occurred before or after that interval. Comparable numbers of continental shelf and slope taxa have first occurrences between 7 and $5 \mathrm{Ma}$, indicating a general change on the continental shelf to upper slope in the latest Miocene which preceded closure of the interoceanic seaway by 2 to $4 \mathrm{~m}$.y. Few extinctions occurred in the last $7 \mathrm{~m}$.y.; $86 \%$ of the common taxa less than $7 \mathrm{~m} . \mathrm{y}$. old in Panama and Costa Rica have survived to the present. The appearance of carbonate-loving species in Panama to Costa Rica at 4.6-5.0 Ma and northern Colombia by $5.0 \mathrm{Ma}$ indicates a well established carbonate regime in the southern Caribbean by earliest Pliocene time. Benthic foraminiferal assemblages show no evidence of upwelling in the Panama-Costa Rican region through the Pliocene.

The Late Miocene environmental changes in shallow Caribbean waters preceded isotopic changes in open-ocean surface waters that occurred 4 to $3 \mathrm{Ma}$. Ecological restructuring took place in the latest Miocene, several m.y. before the seaway closed, and any subsequent environmental changes had little effect on benthic foraminifera of the Caribbean continental shelf. 